\title{
A Prospective Study to the Morphological Variation on Radiological Examination (In Form of Appearance of Ossification Centers in Carpal Bones) in Boys and Girls of Age Group 5 to 12 Years of the Western Rajasthan (Jodhpur) Region.
}

\author{
Ramratan Bishnoi', Gurusharan Koodi² \\ ${ }^{1}$ Ex-Resident, Department of Forensic Medicine, Dr. S.N. Medical College, Jodhpur, Rajasthan, India, ${ }^{2} \| l$ lrd Year Resident, Department of Forensic Medicine, Dr. \\ S.N. Medical College, Jodhpur, Rajasthan, India.
}

\section{Abstract}

Background: The Determination of age of an individual by radiological observation of the time of appearance and fusion of ossification centers is a matter of great medicolegal and academic interest.In the present study estimation of age in the individual of age varying between 5 year to 12 years will, be conducted using the appearance of ossification of carpal bones in boys and girls of the western Rajasthan (Jodhpur) region. Subjects and Methods: A radiological prospective study done on appearances of ossification centers in the carpal bones inboys and girls of age group 5 years to 12 years in western Rajasthan jodhpur region. Results: There were $50 \%$ males and $50 \%$ females in the study with male to female ration of 1:1. Precaution was taken to select equal proportion of cases from each half year interval of age among both sexes. Conclusion: We concluded that trapezium, trapezoid and scaphoid carpals appeared between the age of 5 to 9 years.Their appearance was slightly earlier in females than in males.

Keywords: Age determination, Fusion, Appearance, Wrist Joint.

Corresponding Author: Dr. Gurusharan Koodi, IIIrd Year Resident, Department of Forensic Medicine, Dr. S.N. Medical College, Jodhpur, Rajasthan, India.

Received: June 2019

Accepted: June 2019

\section{Introduction}

In India, even after frequent stress paid on birth and death registration, most of the people not following it, hence the age verification is a great problem among the literates.

In law the crime and punishment is entirely based on criminal responsibility, and this in turn is dependent on age of a person. Court may accept unsworn evidence of a child less than 12 years. Nothing is an offence which is done in good faith for the benefit of a child under 12 years, when such act is done by his or her guardians or on the consent of the guardian, even if the act ultimately causes harm to the child. Also, a child below 12 years can't give a valid consent to suffer any harm which may result from an act done in good faith for his benefit. ${ }^{[1]}$

The Determination of age of an individual by radiological observation of the time of appearance and fusion of ossification centers is a matter of great medicolegal and academic interest. Verification or determination of age is prerequisite for personal identification in living as well as dead.

\section{There are three (3) steps for age estimation}

(1) Physical examination

(2) Dental examination

(3) Radiological examination. ${ }^{[2]}$

The Growth of the human skeleton is of major importance for the aging process as the appearances of ossification of ossification centers and union of epiphysis relate to a fairly definite sequence and time table that makes skeletal maturity a reliable age indicator according to sex and ethnical differences.

The time of appearance and fusion of ossification centers, as observed radio logically is being considered to be a reliable guide for the determination of age of an individual. The appearance of such centers of ossification is spread over a long time. The process of appearance and union has a sequence of time. As a rule, ossification begins centrally in epiphysis and spread peripherally as it gets bigger. Initially it is entirely morphous, rounded and pinhead size, as it grows it takes on the osteological details of bone.

In the present study estimation of age in the individual of age varying between 5 year to 12 years will, be conducted using the appearance of ossification of carpal bones in boys and girls of the western Rajasthan (Jodhpur) region. 


\section{Subjects and Methods}

The radiological prospective study of "appearances of ossification centers in the carpal bones in boys and girls of age group 5 years to 12 years in western Rajasthan jodhpur region" was conducted in western Rajasthan jodhpur region studying in various schools of jodhpur district. The children were selected for the study in the age group of 5 to12 years and are from both the sex boys and girls.

\section{Inclusion Criteria}

- Children of age group 5 to 12 year both male and female were included in study. The Children were selected from either sex and from different socio economic religious and educational status.

- Their age as stated by their parents will be considered along with date of birth certificate and further was confirmed by obtaining birth certificate of from school record.

\section{Exclusion Criteria}

- Subject not consenting for skiagraphy

- Subject not having valid documentation for proof of age / date of birth

- All children below 5 years and above 12 years were excluded from the study

- Children with affecting the growth of bones appearance of fusion centers e.g. congenital deformities fracture cases, chronic illness or on chronic steroid therapy were excluded from the study.

\section{Methodology}

Ethical committee permission was obtained. Individuals of different age group were taking up for study from 5 to 12 years and both the sexes.

- Each individual X - ray wrist - AP View from both the hands taken for study.

- $\mathrm{X}$ - ray wrist - AP View from both the hands was taken with following specification:

i. $\mathrm{KVp}=40-42$

ii. $\mathrm{MAs}=10-13$

- All observation was noted on a common standard proforma and later the findings will tabulated to draw necessary conclusion.

- A predesigned proforma will fill up for every case, master chart was prepared.

\section{Results}

\begin{tabular}{|l|l|l|l|}
\hline Table 1: Number of Cases Examined in Each Age Group \\
\hline $\begin{array}{l}\text { Age Group } \\
\text { In Years }\end{array}$ & $\begin{array}{l}\text { Total No Of } \\
\text { Cases } \\
\text { Examined }\end{array}$ & $\begin{array}{l}\text { Total No Of } \\
\text { Male Cases } \\
\text { Examined }\end{array}$ & $\begin{array}{l}\text { Total No Of } \\
\text { Female Cases } \\
\text { Examined }\end{array}$ \\
\hline 5-6 Years & 18 & 11 & 7 \\
\hline 6-7 Years & 20 & 9 & 11 \\
\hline 7-8 Years & 19 & 11 & 8 \\
\hline 8-9 Years & 19 & 9 & 10 \\
\hline 9-10 Years & 30 & 15 & 15 \\
\hline 10-11 Years & 30 & 10 & 20 \\
\hline 11-12 Years & 34 & 20 & 14 \\
\hline Total & 170 & 85 & 85 \\
\hline
\end{tabular}

There were $50 \%$ males and $50 \%$ females in the study with male to female ration of $1: 1$. Precaution was taken to select equal proportion of cases from each half year interval of age among both sexes [Table 1].

Table 2: Showing comparison in female and male children appearance.

\begin{tabular}{|l|l|l|}
\hline Carpal Bone & Female Children & Male Children \\
\hline Capitate & Below 5 Years & Below 5 Years \\
\hline Hamate & Below 5 Years & Below 5 Years \\
\hline Triquetral & Below 5 Years & Below 5 Years \\
\hline Lunate & Below 5 Years & 6 To 7 Years \\
\hline Trapezium & 5 To 6 Years & 6 To 7 Years \\
\hline Trapezoid & 6 To 7 Years & 6 To 7 Years \\
\hline Scaphoid & 6 To 7 Years & 7 To 8 Years \\
\hline Pisiform & 10 To 11 Years & 11 To 12 Years \\
\hline
\end{tabular}

Table 3: Order of appearance of Carpal bones in all the One hundred seventy cases.

\begin{tabular}{|l|l|}
\hline Females & Males \\
Capitate & Capitate \\
Hamate & Hamate \\
Triquetral & Triquetral \\
Lunate & Lunate \\
Trapezium & Trapezoid \\
Trapezoid & Trapezium \\
Scaphoid & Scaphoid \\
Pisiform & Pisiform \\
\hline
\end{tabular}

\section{Discussion}

This study has been conducted in 170 children of either sex of the age group of 5 to 12 years of Jodhpur region. The children chosen for the study were in the age group of 5 to 6,6 to 7,7 to 8,8 to 9,9 to 10,10 to 11 and 11 to 12 years of both the sexes and belonging to different socio economical religious and educational status. Their ages as stated by them was further confirmed either from birth certificate.

The earlier studies reported that the chronological order of apprance of Carpal Bones were different in males and females. Further they had observed that the Trapezium and Trapezoid appears earlier in females and scaphoid subsequently. They had also reported that in males scaphoid appears earlier to trapezoid and trapezium.

We observed difference in the chronological order of appearance of Carpal bones amongst Jodhpur girls and boys. I found that the Trapezium - Trapezoid appears earlier to that of scaphoid in Jodhpur girls. This finding is similar to that of other various workers. Amongst Jodhpur boys I found that first trapezoid, then trapezium and subsequently scaphoid appears. This observation of the present study is quite different to that of other various workers as others have reported appearance of Scaphoid earlier to that of Trapezoid-Trepezium. Therefore when compared it may be stated that in the present series Trapezoid and Trapezium appear before the appearance of scaphoid bone, whereas the scaphoid appears before the appearance of Trapezoid and Trapezium as per observationof other past workers.

On seeing the Chronological order of appearance of Carpal Bones in females \& males it may also be stated that Trapezoid appears before the appearance of Trapezium in 
males whereas Trapezium appears before the appearance of Trapezoid in females. Thus it may also be stated that the manner of appearance of Trapezium and Trapezoid sequence bears a feminine characteristic. Garn and Rohmann (1960) had also noted that the TrapeziumTrapozoid is a feminine characteristic.

Table 4: Comparison of various studies in males

\begin{tabular}{|c|c|c|c|c|c|c|c|c|}
\hline \multirow[t]{2}{*}{ Studies } & \multicolumn{8}{|c|}{ Total Number Of Male Childern Showing Apperance Of Various Carpal Bone } \\
\hline & Capitate & Hamate & Triquetral & Lunate & Trapezium & Trapezoid & Scaphoid & Pisiform \\
\hline Paterson3 (1929) England & 6 months & 6 months & 3-4 years & $\begin{array}{l}4-5 \\
\text { years }\end{array}$ & 6 years & 6 years & 6 years & $\begin{array}{l}12-14 \\
\text { years }\end{array}$ \\
\hline Flecker (1942)4 Australia & 6 months & $\begin{array}{l}10-11 \\
\text { months }\end{array}$ & 4 years & 4 years & 5 years & 6 years & 6 years & 11years \\
\hline Galstaun5 (1937) Bengal & 6 months & $\begin{array}{l}8-14 \\
\text { months }\end{array}$ & 3-4 years & 5 years & 7 years & 4-7 years & $7-11$ years & $\begin{array}{l}12-17 \\
\text { years }\end{array}$ \\
\hline $\begin{array}{l}\text { Hasan\& Narayan6 (1963) } \\
\text { U.P. }\end{array}$ & $\begin{array}{l}\text { Within } 6 \\
\text { months }\end{array}$ & $\begin{array}{l}\text { Within } 6 \\
\text { months }\end{array}$ & 5 years & 6 years & 8 years & 7years & 7 years & 13 years \\
\hline $\begin{array}{l}\text { Present Study, Jodhpur } \\
\text { (Raj.) }\end{array}$ & $\begin{array}{l}\text { Below } 5 \\
\text { years }\end{array}$ & $\begin{array}{l}\text { Below } 5 \\
\text { years }\end{array}$ & $\begin{array}{l}\text { Below } 5 \\
\text { years }\end{array}$ & $\begin{array}{l}6-7 \\
\text { years }\end{array}$ & $6-7$ years & $6-7$ years & $7-8$ years & $\begin{array}{l}11-12 \\
\text { years }\end{array}$ \\
\hline
\end{tabular}

Table 5: Comparison of various studies in females

\begin{tabular}{|l|l|l|l|l|l|l|l|l|}
\hline \multirow{2}{*}{ Studies } & \multicolumn{2}{|c|}{ Total Number Of Female Childern Showing Apperance Of Various Carpal Bone } \\
\cline { 2 - 8 } & \multicolumn{1}{|c|}{ Capitate } & Hamate & \multicolumn{1}{|c|}{ Triquetral } & \multicolumn{1}{|c|}{ Lunate } & Trapezium & Trapezoid & Scaphoid & \multicolumn{1}{c|}{ Pisiform } \\
\hline Paterson (1929)3 England & 6 months & 6 months & $2-3$ years & $3-4$ years & $4-5$ years & $4-5$ years & 6 years & $\begin{array}{l}9-10 \\
\text { years }\end{array}$ \\
\hline Flecker (1942)4 Australia & 6 months & $\begin{array}{l}10-11 \\
\text { months }\end{array}$ & $3-4$ years & 3 years & 5 years & 6 years & 4 years & 10 years \\
\hline Galstaun (1937)5 Bengal & 6 months & $\begin{array}{l}8-14 \\
\text { months }\end{array}$ & $2-3$ years & 5 years & $5-6$ years & $5-6$ years & 6 years & $\begin{array}{l}9-12 \\
\text { years }\end{array}$ \\
\hline $\begin{array}{l}\text { Hasan\& Narayan (1963)6 } \\
\text { U.P. }\end{array}$ & $\begin{array}{l}\text { Within 6 } \\
\text { months }\end{array}$ & $\begin{array}{l}\text { Within 6 } \\
\text { months }\end{array}$ & 3 years & 6 years & 6 years & 6 years & 7 years & 11 years \\
\hline Present Study, Jodhpur (Raj.) & Below 5 years & $\begin{array}{l}\text { Below 5 } \\
\text { years }\end{array}$ & $\begin{array}{l}\text { Below 5 } \\
\text { years }\end{array}$ & $\begin{array}{l}\text { Below 5 } \\
\text { years }\end{array}$ & $5-6$ years & $6-7$ years & $6-7$ years & $\begin{array}{l}10-11 \\
\text { years }\end{array}$ \\
\hline
\end{tabular}

\section{Conclusion}

We concluded that trapezium, trapezoid and scaphoid carpals appeared between the age of 5 to 9 years. Their appearance was slightly earlier in females than in males.

\section{References}

1. Davies, D.A. and Parson (1927): F.H.: JI. Anatomy 62: 58.

2. Basu, S.K. and Basu, S. (1938): Ind.J.Paediat. 5: 201.
3. Paterson RS. Some factors influencing epiphyseal growth and union January 18, 1929:691-695.

4. Flecker H. Time of appearance and fusion of ossification centers as observed by roengetographic methods: American Journal of Roengetology; 1942,47,97-159.

5. Galstaun G. (1937); A study of ossification as observed in Indian subject. Indian Journal Medical Research (IJMR), Vol. 25,267-324.

6. Hasan, M. and Narayan, D. (1964), Radiological study of the postnatal ossification of the upper end of Humerous in U.P. Indians. J. Anat. Soc. India, 13: 70-75.

Copyright: () the author(s), 2019. It is an open-access article distributed under the terms of the Creative Commons Attribution License (CC BY 4.0), which permits authors to retain ownership of the copyright for their content, and allow anyone to download, reuse, reprint, modify, distribute and/or copy the content as long as the original authors and source are cited.

How to cite this article: Bishnoi R, Koodi G. A Prospective Study to the Morphological Variation on Radiological Examination (In Form of Appearance of Ossification Centers in Carpal Bones) in Boys and Girls of Age Group 5 to 12 Years of the Western Rajasthan (Jodhpur) Region. Asian J. Med. Res. 2019;8(3):FM01-FM03.

DOI: dx.doi.org/10.21276/ajmr.2019.8.3.FM1

Source of Support: Nil, Conflict of Interest: None declared. 